\title{
Şiirle Gerçeklik Arasına Sıkışmış Bir Şair: Nîmâ Yûşic
}

\author{
Yeşim IŞIK BAĞRIAÇIK*
}

\begin{abstract}
ÖZ
Modern İran şiirinin kurucusu olan Nîmâ Yûşic, şiirinin oluşum aşamasında birçok eleştiriye maruz kalmıştır. Buna rağmen doğru bulduğu şiir anlayışını şekillendirmekte tereddüt etmemiş, hayatı boyunca bu uğurda mücadele etmiştir. Kendisine karşı sergilenen olumsuz tavırlar onun içine kapalı karamsar bir havaya bürünmesinde etkili olmuştur. İnsanlardan uzakta köy hayatında huzuru bulan Nîmâ Yûşic, çocukluk anılarına sığınmıştır.

Nîmâ Yûşic, şairliğinin ilk yıllarında romantik şiire meyletmiştir. Onun ilk şiir deneyimlerini yayımladığı Rıza Şah Dönemi’nde, İran edebiyatında romantizm akımına ilgi olduğu görülmektedir. Burada kastedilen romantizm tam olarak batılı anlamda bir romantizm değil, Nîmâ Yûşic ile başlayan ve tarihi süreç içerisinde şekillenen bir romantik anlayıştır. 1921 yılında darbe ile gücü ele geçiren ve bütün muhalif sesleri susturan Rıza Han, 1925'te askeri rejimle yönetime el koymuştur. Bu dönemde yayın organları, gözetim altına alındığ1 için hükümete ve ülkenin durumuna ilişkin her türlü eleştiri ve ima kısıtlanmıştır. Meşrutiyet inkılabından sonra en gelişmiş tarz olan siyasi şiir silikleşmiştir. Böylece Nîmâ Yûşic'in Fransız romantiklerinin etkisiyle şekil verdiği İran romantik şiiri kendine özgü bir hal almıştır. Nîmâ’nın romantik şiirlerinde görülen eğilimleri, toplumsal sorunlardan ötürü ümitsizliğe kapılma, içine kapanma, yalnızlığa ve tabiata sı̆̆ınma, dönemin diğer şairlerinde de görmek mümkündür. Özellikle şairin ruhsal ve düşünsel boyutuyla örtüşen bu özellikler "Efsane" adlı şiirinde gün yüzüne çıkmıştır. "Efsane” âdeta bu dönemde romantik şairlerin manifestosu mahiyetindedir.
\end{abstract}

Dr. Öğr. Üyesi, Gümüşhane Üniversitesi, Edebiyat Fakültesi, Türk Dili ve Edebiyatı Bölümü, Gümüşhane/Türkiye

E-posta:yesimisik_29@hotmail.com,ORCID:0000-0002-4603-8990,DOI: 10.32704/erdem.948846 Makale Gönderim Tarihi: 19.09.2019 * Makale Kabul Tarihi: 15.12.2020 * (Sanat ve Edebiyat Mk.) 
1941 y1lından itibaren Nîmâ Yûşic, romantik şiiri bir tarafa bırakarak toplumsal ve siyasi içerikli şiirlere yönelmiştir. $\mathrm{O}$ bu şiirlerinde sembolik bir dil kullanmıştır. Sembolik şiire geçiş aşamasında Nîmâ, önce klasik İran şiirlerinde nasihat içerikli, ahlaki mesajlar veren, kinayeli bir anlatımın olduğu şiirlere öykünmüştür. 1940'lı yıllarda yazdığı bu şiirler genellikle fabl türündedir. Daha sonra oluşturduğu sembolik şiirlerinde dolaylı bir anlatımla toplumun gerçeklerini ifade etmeye çalışmıştır. Hikâyemsi bir boyuta sahip sembolik şiirlerinde doğrudan eleştirel bir dil kullanmayan şair, toplumsal ve siyasi olayların sonucunda oluşan ortamları tasvir ederek var olan durumu ortaya koymuştur. Bu şekilde İran edebiyatında toplumsal meselelerde sembolik bir dil kullanılması Nîmânın şiiriyle başlamıştır. Nîmâ Fransız sembolik şiirinin etkisi altında, hayvanların farklı özelliklerinden faydalanarak onları insanın şahsiyetini ve ruhi durumunu ifade ederek, farklı özelliklerini şiirlerine yansıtmıştır. Halkın çektiği sıkıntıları dert edinen Nîmâ, şiirlerinde onların fakirliklerini, mahrumiyetlerini ve uğradıkları haksızlıkları dile getirmiştir. Gerçek şiirin yaşadığı toplumu yansıtması gerektiğini düşünen şair, şiirleriyle halkta bir farkındalık yaratmayı istemiştir.

Anahtar Kelimeler: Nîmâ Yûşic, modern şiir, romantik şiir, siyasitoplumsal içerikli şiir, sembolik şiir. 


\section{A Poet Confined Between Poetry And Reality: Nima Yushij}

\section{ABSTRACT}

The founder of modern Persian poetry, Nima Yushij has been subjected to criticism during the formation of his poem. However, he did not hesitate to shape his sense of poetry and fought for that for the rest of his life. The negative attitudes towards him caused him to be introvert and in pessimistic mood. Nima Yushij, who found peace in the village life, away from people, nestled in his childhood memories.

In his early periods, Nima Yushij was in tendency of romance poetry. During the reign of Reza Shah, when Nima Yushij published his first poems, there seems to have been an interest in the romanticism movement in Iranian literature. The romanticism that is meant here is not exactly a romanticism in the Western sense, but a romantic understanding that begins with Nima Yushij and takes shape in the historical process. Reza Khan, who seized power with a coup in 1921 and silenced all dissident voices, confiscated the administration with the military regime in 1925. During this period, all kinds of criticism and insinuations about the government and the state of the country were restricted, as the publications were under surveillance. After the constitutional revolution, political poetry, the most developed style, became indistinct. Thus, Iranian romantic poetry, which Nima Yushij shaped under the influence of French romantics, became idiocratical. It is possible to see the trends seen in Nima's romantic poems, such as despair due to social problems, introversion, taking shelter in solitude and nature, as well as in other poets of the period. In particular, these features, which coincide with the spiritual and intellectual dimension of the poet, appeared in his poem "Efsane". The "Efsane" is almost the manifesto of Romantic poets during this period.

Nima Yushij has placed his romantic poetry on one side in 1941 and moved towards social and political poems. He used a symbolic language in these poems. At the stage of transition to symbolic poetry, Nima imitated the poems in classical Iranian poetry, where there was a suggestive narrative that provided sermon, moral and allusive messages. These poems, which he wrote in the 1940s, are often in the fable type. Later, he tried to express the realities of society with an indirect narrative in his symbolic poems. The poet, who did not use direct critical language in his symbolic poems with a story-like dimension, revealed the existing situation by depicting the environments formed as a result of social and political events. In this way, the use of symbolic language in social issues in Iranian literature began with Nima's poetry. Under the influence of French symbolic poetry, Nima took advantage of the 
different characteristics of admirers to reflect their different characteristics in his poems, which would express the personality and spiritual state of man. In his poems, Nima, who worries about the troubles of the people, expressed their poverty, deprivation, and injustice they suffered. The poet, who thought that real poetry should reflect the society, wanted to create awareness in the public with his poems.

Keywords: Nima Yushij, contemporary poetry, romantic poetry, political-social poetry, symbolic poetry. 


\section{Giriş}

$\mathbf{Y}$ eni şekil alan İran şiirinde Nîmâ Yûşic, modern çağın sorunlarını klasik şiir kalıpları ve söz varllğıyla dile getiremeyeceğini anlamış, hayatı boyunca birçok şairin farkına bile varmadığı modern dünyanın ihtiyaçlarına cevap verebilecek bir şiir tarzı oluşturmaya çabalamıştır (Yıldırım 2011: 144). Nîmâ Yûşic kendi toplumunda alışılmadık, yeni bir şiir anlayışı ortaya koyarken muhaliflerinin şiddetli eleştirilerine maruz kalmıştır. Eğitim tarzı tenkit edilmiş, iş hayatında istifaya zorlanmış, işten çıkarılmış, işsiz ve parasız kalmış, sakin ve huzurlu bir hayat yaşayamamıştır (Hamîdîyân 1383: 21). Öyle ki şaire karşı sergilenen düşmanca tavırlar onun ilerlemesi önünde engele dönüştüğü gibi günlük yaşantısında da onu sıkıntıya sokacak düzeylere ulaşmıştır (Pûrnâmdâriyân 1389: 101). Buna rağmen doğru olduğuna inandığı şiirin kavgasını vermiştir (Kırlangıç 2010: 119). Harfha-yi Hemsaye adı ile yayımlanan farazi komşusuna yazdığı mektuplarda bu konuya değinmiş, her türlü eleştiriye karşı şiirini şekillendirmeye çalışan genç şaire, kimseye kulak asmadan, sanatını olgunlaştırmak için bildiği ve inandığı şekilde gayret göstermesini tavsiye etmiştir (Yûşic,1385: 197).

Nîmâ Yûşic hayattayken modern İran şiirinin kurucusu olarak tanımlandığında buna itiraz eden şair ve yazarlar olmuştur, çünkü Meşrutiyet Dönemi’nde yazılan şiirlerde şekil ve muhteva olarak bazı yenilikler yapıldığı bilinmektedir. Mesela Mirzâde-i Işkî şiirin kafiye düzeninde yenilikler yapmış (Ruzbe 1391: 123), Îrec-i Mîrzâ şiirin muhtevasında getirdiği farklı bakış açısıyla mizah dolu şiirler yazmış (Şâfeî 1380: 270), Ebu'l-Kasım-1 Lâhûtî kafiye ve veznin sıkı kurallarını gevşetmiş, sade şiirler kaleme almıştır (Şâfeî 1380: 28). Benzer şekilde Takî-i Rifat klasik şiirdeki vezin eşit olması gerektiği kuralını çiğnemiş ve kafiye düzenini bozmuştur (Lengrûdî 1387: 52). İsmini anmadığımız benzer yenilikler yapan diğer şairler de olmak üzere bu dönem şairleri, sistemli ve bütünlüklü bir şiir anlayışı ortaya koyamamışlardır (Lengrûdî 1387:108). Nîmâ Yûşic’i İran modern şiirinin kurucusu olarak gören Mehdi-i Ehavân-i Sâlis, onun yaşarken insafsızca eleştirildiğini ifade etmiştir (Sâlis 1369: 472). Bedayi' ve Bid'atha ve Ata ve Lika-yi Nîmâ Yûşic adlı kitabında şairin şiirini değerlendirmiş, ona yöneltilen eleştirilere açıklık getirmeye çalişmı̧̧tır.

Nîmâ Yûşic'in yaşadığı dönemin ihtiyaçları ve özel yaşamındaki gelişmeler onu farklı şiir ekollerini yöneltmiştir. Rıza Şah dönemine (1925-1941) denk gelen gençlik yıllarında Nîmâ’nın daha çok romantik eğilimler gösterdiği fa- 
kat daha sonra realist bir yaklaşım sergilediği ifade edilmiştir. Şairin şiirini tam olarak bir yere nispet etmek oldukça zordur. Toplumcu, sloganist ve realist bir şairin de her türlü romantik duygu ve düşüncelerden beri olduğunu düşünmek doğru olmayabilir (Hamîdîyân 1383: 21-22).

Nîmâ Yûşic eleştirilip dışlandığı durumlarda içine kapanıp uzlete çekilmiş, tabiat içerisindeki huzurlu hayatına ve çocukluk anılarına sığınarak geçmişin özlemiyle yaşamıştır. Yaşamı boyunca kendisine olumsuz tavır alan insanların ve maruz kaldığı olumsuz davranışların onda uyandırdığı duyguları şiirlerine yansıtmıştır (Pûrnâmdâriyân 1389: 101). Bu anlamda Nîmânın romantik eğilimleri inzivaya çekilmesi ve bu durumu açıkça sevip övmesidir. Nîmâ’nın hayattı siyah-beyaz, hayır-şer olarak iki uç noktada değerlendirmesi de onu romantik bir anlayışa yöneltmiştir. Hayata sorgulayıcı bir bakış açısıyla bakan Nîmầnın şiirinin kemale erdiği zamanlarda ne tam anlamıyla eleştirel tavrını sürdürdüğünü ne de tam olarak vazgeçtiğini görülmektedir. Şairin sosyal hayatta yaşadığı sorunlarının etrafındakilere karşı negatif bir bakış açısı geliştirmesinde etkili olduğu söylenmiştir. Topluma uyum sağlayamadığı durumlarda sinirlilikle hatta delilikle ve tehlikeli bir ruh hastası olmakla itham edilmiştir (Hamîdîyân 1383: 24).

Nîmâ Yûşic sosyal ilişkilerinde yaşadığı olumsuzlukların yanı sıra duygusal ilişkilerinde de hayal kırıklığı yaşamıştır. Gençlik döneminde ilk kez âşık olduğu kızdan olumlu yanıt almamıştır. Evlenmek istediği köylü kızı ise şehirde yaşamayı göze alamayınca şair, ikinci kez hayal kırıklı̆̆ına uğramıştır. Yaşadığı bu tecrübelerin uzun süre etkisinde kalan Nîmâ Yûşic kendini şiir sanatına vermiştir (Âryenpûr 1387: 467).

Yaşadığ1 tecrübelerin etkisiyle olsa gerek Nîmâ Yûşic, şiirlerinde aşk mefhumunu olumlu bir bakış açısı ile değerlendirmez. Muhtemelen şair gençken edindiği tecrübeler sonucunda bir kadına ve güzelliğe karşı duyulan aşkın acıdan başka bir şey getirmeyeceği anlayışına varmıştır. "Mafsade-i Gol” adlı şiirde sevgiliyi kastettiği gül ile ilgili düşünceleri şöyledir:

Gülün işi budur, zahiri güzel fakat batını adım öldürür Olmasaydı dünyada güzel yüzlüler günler acı olmazdı (Yûşic 1389:97).

Nîmâ Yûşic şiirlerinde zahiri güzellikten kaynaklanan aşktan uzak durmuş, ondan bahsetmemiştir. Böyle bir aşk sanki onun acılarının ve mutsuzluklarının kaynağı olmuş, onun özgür ve köylü ruhuyla örtüşmemiştir. Şairin ruhuna ve zihnine hâkim olan bu tarz bir aşkı kendisi ve her gerçek şairin kaderi olarak görmektedir. "Yadgar" adlı şiiri bu konuya işaret etmektedir (Pûrnâmdâriyân 1389: 101): 
Buradır aşkın geldiği ve beni çocukların halkasından çıkardığı yer Gülümsemenin dudağımdan silindiği gönlümün hicranların içinde kaldığı yer

Gözün firakın acısıyla gözyaşları döktüğü yer (Yûşic 1389:91).

\section{Nîmâ Yûşic'in Romantik Şiirleri}

Rıza Şah Dönemi edebiyatında dikkat çeken unsurlardan biri de romantizme yöneliştir. Elbette romantizmden kast edilen şey tam olarak batılı anlamda bir romantizm değildir. Burada Nîmâ Yûşic ile başlayan ve onun döneminde süren romantik anlayış kastedilmektedir. Geniş anlamıyla kast edilen bu romantizm anlayışını elbette Nîmâ Yûşic batı edebiyatından etkilenerek oluşturmuştur. Fransız romantizminin etkisinde oluşan bu türün bazı özelliklerini gerek Nîmânın gerekse onun takipçilerinin eserlerinde görmek mümkündür. Toplumsal sorunlardan ötürü ümitsizliğe kapılma, içine kapanma, yalnızlığa ve tabiata sığınma Nîmầnın şiirlerinde özellikle "Efsane" adlı şiirinde görülen bariz özelliklerdendir. Bu eser romantik şiirin manifestosu olarak algılanmıştır (Şefî Kedkenî 1390: 50). Nîmâ Yûşic modern insanın duygu dünyasını yansıtan bir şairdir. Romantik ve toplumsal içerikli şiirlerinde varlığı ve insanı, modern bireyin ihtiyaçlarına ve duygu dünyasına göre yorumlamıştır (Abbâs Âbâd 1390: 91).

Nîmânın şairliğinin ilk on yılında şiirleri romantik unsurlarla doludur. Bu şiirlerine siyasi ve toplumsal olaylar doğrudan yansımamıştır. Başlıca romantik şiirleri "Gesse-yi Rengperide”, "Ey Şeb”, "Efsane”, "Yadgar”, "Taslim Şode”, "Şem’e-i Kareci, “Ku”, "Der Cevar-i Sahtsar”, "Dihkana”, "Hoşi-yi Man”, "Hatere-yi Amonaser”dir. Bu şiirler, özellikle ilk dört şiiri, 1920-1931 yılları arasında yazılmış olup romantik şiirin birçok unsurunu içlerinde barındırmaktadır (Caferî 1386: 237).

"Gesse-yi Rengperide” Nîmâ Yûşic’in doğrudan kendi ruh dünyasıyla örtüştürüldüğü şiirlerindendir. Bu şiirinde sanki şair geçmişinden, incinmiş kırılmış ruhundan okuyucuyu haberdar etmek istemektedir. Çocukluk döneminin sarhoş edici mutluluğundan bahsettiği şiirde Nîmâ yetişkinlerin dünyasına adım atmaktadır. Bu dönemde de zorluklar yaşayarak bocalayan şair içindeki çocukluğu korumaya gayret eder. Aşkın acı ve dertlerine duçar olur, insanlardan kaçıp kendini çöllere ve dağlara vurur. Çocukluğundan itibaren yanında daima varlığını hissettiği aşk ile içten içe sohbet edip kederini onunla paylaşır. Aşk şaire karşlık vermeyince şair yanıp yakılmaktan başka 
çare olmadığını anlar. Çocukluk anılarına dalar ve inzivaya çekilir. Onu yalnız bırakan insanlardan, vefasız yardan şikâyet eder. Köy hayatını över ve şehir hayatını eleştirir. Şair bütün dertlerinin kaynağının aşk olduğuna inanır:

Ah ne yazık ki karardı bahtım! Ah bu güçlü aşkın peşinde, ah, ah!

Nerede o çocukluk günleri! Nerede o mutluluklar?

Sevinçlere, neşelere ne oldu?

Ne oldu o yüzümün rengine ve o halime;

O ilk emellerim yok oldu!

Kaçt1, rengim üzüntü ve kederden

Bu benim: rengi kaçan, kanı çekilen (Yûşic 1389: 25).

$\mathrm{Bu}$ şiirdeki romantik unsurlar; çocukluk dönemine özlem duyma, tabiata s1ğınıp onunla dertleşme, halktan kaçış ve inzivaya çekilme, münzevi sanatçılar1 övme, içindeki acıları tekrar tekrar dile getirme, şehri her türlü kötülüğün kaynağı görme ve köy yaşamını övmedir.

Konu olarak yeni olan "Gesse-yi Rengperide"de şair şiirin şekline bakmaksızın coşku dolu duygu ve düşüncelerine öncelik vermiştir. Yine de mesnevi tarzında ve klasik dil özelliklerini taşıyan bu şiirdeki değişiklikler sınırlıdır. Fakat "Ey Şeb" adlı şiirin muhteva ve şeklindeki yeniliklerinin boyutu daha geniştir (Caferî 1386). "Ey Şeb” şiiri meşrutiyet döneminde kemale ermiş en iyi romantik şiirlerinden biri olarak değerlendirilmiştir. Muhteva olarak tamamen yeni olan şiirde Nîmâ Yûşic, tabiatla iç içe yeni bir hayal dünyası kurgulamaktadır. Birinci tekil ağzıyla konuşan şairin bireyci yaklaşımı yine dikkat çekmektedir (Caferî 1386: 243- 245). Kişisel duygularını ifade ettiği şiirde geceyi muhatap alan şair aynı zamanda geceyi acılarının kaynağı olarak görür:

Hayret doğrusu, ey uğursuz vahşet saçan gece!

Ne zamana kadar yakacaksın canımı?

Ya çıkar gözümü yerinden,

Ya kaldır perdeyi yüzünden,

Ya birak öleyim

Usandım yaşamaktan (Yûşic 1389: 42).

"Efsane" sadece Nîmâ'nın en önemli romantik şiiri olmayıp modern İran edebiyatının en sanatsal romantik eseri olarak görülmüştür (Caferî 1386: 250). 1940 yılında yayımlandığında Nîmâ Yûşic uzun süre "Efsane'yi yazan şair" olarak anılmıştır. Şiirin yeni bir şekil ve tarzda yazılması şaire büyük bir başarı kazandırmıştır (Hamîdîyân 1383: 47). 
Bu şiirde Nîmâ Yûşic Avrupa'daki romantik şairler gibi şiiri klasik şiirin klişeleşmiş kalıplarından çıkarıp serbest bir şekle sokmaya çalışmıştır. "Efsane", dramatik bir tiyatro şeklinde Âşı ile Efsane'nin karşılıklı konuşmasından oluşmaktadır. Âşık, doğada dertli ve kederli bir şekilde inleyen şairin kendisi olarak yorumlanmıştır. Farklı boyutları ve birkaç yüzü olan Efsane'nin ise bir taraftan aşkı temsil ettiği diğer taraftan da şairin bilinçdışını, iç dünyasını yansıttı̆̆ı ifade edilmiştir. Her hâlükârda şiirin tamamında ve özelde Efsane'nin şahsiyetinde görülen bu müphem ve gizemli boyut, Avrupa romantik şiirinin asli özelliklerinden biri olarak değerlendirilmektedir. Modern İran edebiyatında ilk defa Nîmầnın şiirinde hayat bulan bu özelliklerde (Caferî 1386: 256-258) Fransız romantiklerinden Alphonse de Lamartine ve Alfred Domas etkisi görülmektedir. "Efsane" bir takım kusurlarına rağmen sanat anlayışı ve beyan şekli olarak yeni sayılmıştır. Âşık ve Efsane'nin karşılıklı konuşması olan şiirde şair, hayal kırıklığına uğradığı kendi aşk hikâyesini, arzu ve heveslerin aldatıcılığını, hayat acılarını ve kötümser bakış açısını ifade etmektedir. Dağların eteklerinde, derelerin arasında baharın letafetiyle ortaya koyduğu tabiat manzaraları arasında sahnelenen şiirde, geçmişe olan hasret yansitılmıştır (Âryenpûr 1387: 472-474).

"Efsane"de romantik şiirin en belirgin özelliklerinden olan tabiata meyil bariz bir şekilde görülmektedir. Nîmâ, şiirinde doğa unsurlarını ayrıntılı ve sıra dışı bir şekilde tasvir etmiş kendine özgü bir bakış sergilemiştir. Onun şiirinde beşeri hususiyetleri taşıyan tabiat insanla bütünleşmiştir. Şiirde şair, âşık ya da romantik bir insanın tasviri olarak karşımıza çıkmaktadır. Şehirden, insanların vefasızlıklarından ve halktan kaçıp hatıralara ve doğaya sığınan bu insan, aslında içinde bulunduğu yenidünyanın acılarından kurtuluşu geçmişin müphem hatıralarında ve tabiatta aramaktadır. Klasik şiirlerdeki aşk anlayışının aksine, aşka ulvi değerler atfetmeyen şair, aşkın hayali bir unsur olduğunu ve insanların gerçek aşkın değil, menfaatlerin peşinde olduğuna inanmaktadır (Caferî 1386: 264). Hümanizmin etkisinde kalan şairin dünya görüşünün temelini Bâkî olana karşın ölümlü olan insana aşk anlayışı oluşturmaktadır (Ruzbe 1391: 71). Klasik İran şiirinin en önemli temsilcilerinden olan Hâfız-1 Şirâzîye seslenen Nîmâ, bu anlayışını aşağıdaki dizelerle ifade etmiştir:

Ey Hafiz! Bu ne hile ve yalandır Şarap, kadeh ve sakinin diliyle söylenmiş?

Sonsuza kadar ağlasan yine de inanmam

$\mathrm{O}$ aşk oyunlarının bâkî olduğuna

Ben gidici olana âşı̆̆ım (Yûşic 1398: 72). 
Bireyin ön planda olduğu romantik şiirlerde şairler içinde bulundukları 1stırab1 şiirlerinde dile getirmişlerdir (Huseynî 1387:184) Bu bağlamda Nîmầnın gerçek duygularıyla örtüştürülebilecek şu dizeler onun hayata bakışını yansıtyyor olabilir:

Efsane: evet, evet

Kararsız bir aşı̆̆ın hikâyesiyim.

Ümitsiz, 1stırap dolu

Üzüntüden gece ayakta kalan

Yillarca keder ve inzivada yaşayan.

Korku dolu bir aşığın hikâyesiyim

Sahra devi gibi korkunçsam,

Ve eğer beni ihtiyar köylü bir kadın

İnsanların kaçtı̆̆ı bir dev gibi görüyorsa,

Cihanın ıstırabının oğluyumdur da ondan (Yûşic 1389: 56-57).

Şairin başka bir boyutunu; aşkı, rüyası, hayal dünyası ya da bilinçdışını da ifade eden Efsane, şiirde şairle dertleşmektedir. Ona insanın akıl ve aşkın mücadelesi arasında kaldığını ve en iyisinin kendisi ile yani Efsane ile baş başa yaşaması olduğunu söylemektedir. Şair, Efsane'nin söylediklerini kabul etmeyerek doğada hatıralara sığınıp gönlünü hoş tutmayı yeğler. Ama çok geçmeden Efsane kendisinin aslında akıllı kişilerin uzak durduğu bir yalan, tam da şairin istediği bir aldatmaca olduğuna şairi inandırır. Böylece romantik şair kendini Efsane'ye teslim etmekte çareyi bulur. Bu bağlamda Nîmâ Yûşic Avrupa'daki romantikler gibi aşka sığınır, bilinçli olarak kendini kandırır. Bu dönemde meşrutiyet inkılabının sonuçsuz kalması, yeni bir toplumsal düzenin şekil alması ve özel hayatında yaşadığı hayal kırıklıkları şairin bu ruhi durumunda etkili olmuş olabilir (Caferî 1386: 266-268).

\section{Nîmâ Yûşic'in Siyasi- Toplumsal İçerikli Şiirleri}

1921 yılında darbe ile Rıza Han, gücü ele geçirmiş ve halkın direnişini bastırarak bütün muhalif sesleri susturmuştur. 1925'te kurduğu meclisle Ahmed Şah'ı azlederek Şahlık makamına oturmuş, askeri rejimle yönetime el koymuştur. Bu dönemde yayın organları gözetim altına alındığı için toplumsal eleştiriler kısıtlanmıştır ve sembolik bir dil yaygınlaşmıştır. Meşrutiyet inkılabından sonra en gelişmiş tarz olan siyasi şiir silikleşmiştir. Bu dönemde Nîmâ Yûşic Fransız romantiklerinin etkisiyle yeni bir tarzın kurucusu 
olmuştur (Âjend 1363: 186-187). Nîmâ Yûşic 1920 ve 1953 yıllarında olmak üzere hayatı boyunca iki darbeye şahit olmuştur. I. Dünya Savaşı, Kaçar hanedanının yıkılışı, emperyalist devletlerin Rıza Han'ı iktidara getirmesi, 1953 darbesi, güney ve kuzey petrollerinin paylaşılması İran halkına fakirlik ve yoksulluktan başka bir şeye sebep olmamıştır (Karaguzlu 1386: 216). Bu arada II. Dünya Savaşı başlamış, İran, İngiliz ve Rus askerlerinin işgaline uğramıştır. Tahran işgal edilmiş, Rıza Şah istifaya zorlanıp yerine oğlu getirilmiştir. Tudeh partisi kurulmuş ve daha sonra faaliyetleri kanundışı sayılmıştır. Rus ve İngiliz güçlerinin çekilmesinin ardından Amerika tedricen İran’a nüfuz etmeye başlamı̧̧ Muhammed Musaddık liderliğinde Ayetullah Kâşânînin himayesinde petrolün millileşmesi için başlayan mücadele başarıya ulaşmıştır. 1953 yılında yapılan darbede Amerika casusluk örgütünün yardımıyla Musaddık Hükümeti devrilerek Şah yeniden devletin başına getirilmiştir. Böylece darbeden sonra ülkede yine boğucu ortam hâkim olmuştur (Pûrnâmdâriyân 1389: 110). Halkın birbirine düşmesi, erkeklerin savaşa gidip geri dönmemesi, askerlerin ölüp geride kadın ve çocukları bırakması ve bir taraftan belli bir kesimin ülkenin kaynaklarını kendi çıkarı için kullanarak zenginlik ve refah içinde yaşaması Nîmâ’nın gerçek acılarının kaynağı olmuştur. Şair yaşanılan bu acılara şiirlerinde kendi dünya görüşüne ve şiir anlayışına göre tepki vermiştir (Karaguzlu 1386: 216).

Rıza Han Dönemi’ndeki boğucu ortam sonucunda Nîmâ Yûşic, giderek umutsuzluğa kapılmaya başlamıştır. Şiirlerinde daha çok kendi ruh durumunu ifade etse de toplumcu bir şairdir. Nitekim dünyanın karmaşık halinden çıkıp umut dolu güzel günlere kavuşması bütün dünya şairleri gibi onun da beklentisidir. Fitrat olarak ümit dolu ve sorumluluk sahibi olan şair, insanl1ğın mutlu olmasını arzu etmektedir. İçinde bulunduğu karamsar ortamın her an değişeceğine ve her şeyin düzeleceğine olan umudu şiirlerine yansımıştır. Mesela "Morg-i Âmin" adlı şiirde Âmin Kuşu karanlık dünyayı aydınlatacak ve sessizliğe gömülen şehri harekete geçirecek bir ışığı müjdelemektedir. Benzer şekilde "Padşah-i Fath"de kışın korkunç soğuğunda kurumuş erguvan ağacı mucizevi şekilde çiçek açacaktır (Hukûkî 1389: 27-29):

Böyle korkunç bir sonbaharda

Çiçek açamama korkusuyla erguvan,

Yiten ümitlerinden yorgun düşer

Ümit dolu tebessümüyle tomurcuk verir o, baharda

Çiçek açar (Yûşîc 1389: 638). 
Nîmânın siyasi şiirleri meşrutiyet döneminin ateşli şairlerinin söylemlerine benzememektedir. Onun siyasi şiirleri Meşrutiyet Dönemi şiirleri gibi sloganist değil daha mutedil, sanatsal ve şairane niteliktedirler. "Morg-i Âmin", "Padeşah-i Fath", "Hanevade-yi Serbaz", "Kar-i Şebpa”, "Vay ber Man”, "Ay Ademha”, "Feryad Mizanam" gibi şiirlerinde bu özellikler görülebilir. Bu şiirler aynı zamanda Fars şiirinin en iyi siyasi şiirleri olarak değerlendirilmiştir. Nîmâ Yûşic şiirleri siyasi şiirlerinde belli bir dönem ve belli kişileri eleştirmemiş genel bir çerçeve içerisinde tarihteki bütün baskıcı ve sömürgeci yönetimleri hedef almıştır. Bu bağlamda evrensel bir bakış açısına sahip olduğu söylenebilir (Karaguzlu 1386: 57-59).

1941-1953 yılları arasındaki dergilere bakıldığında Nîmâ’nın bu yıllarda dikkat çeken bir isim olduğu görülmektedir. Şairin artık romantik şiiri bir tarafa bıraktığı tamamen toplumsal ve siyasi içerikli şiirlere yöneldiği anlaşılmaktadır. Bu bağlamda Nîmâ şiirlerinde daha ziyade toplumsal içerikli sembolik bir dil kullanmaya başlamı̧̧ıı (Şefî Kedkenî 1380: 55).

Siyasi ve içtimai ortam Nîmâ’nın şiirine doğrudan yansımamıştır. Şair siyasi olayların topluma yansımasıyla daha çok ilgilenmiş, yaşanılan tarihi olaylar karşısında insanların verdiği tepkileri şiirlerinde daha çok ön plana çıkarmıştır. Bu bağlamda halkın yaşadığı fakirlik ve sıkıntılar, şair ve edebiyatçıların makama ve maddiyata olan düşkünlükleri sonucunda ahlaki değerleri bir tarafa bırakarak yalancılığa tenezzül etmesi, halk taraftarı gibi gözükmeye çalışan ama aslında halkı sömüren siyasetçiler ve sömürgeci devletler Nîmầnın şiirlerinde yer verdiği konulardır. Yaşanılan olumsuz gerçekler şairin şiirinde üzüntü, keder, mutluluk, ümit, hasret ve öfke şeklinde tezahür etmiştir. Özellikle 1937 y1lından önceki şiirlerinde bu durumu müşahede etmek mümkündür (Pûrnâmdâriyân 1389: 110).

Nîmânın şiirindeki yeni dil ve düşünce dünyasının her ne kadar kişisel tecrübelerinden oluştuğu ifade edilse de onun oluşturduğu bu dünyanın toplumdan neş'et ettiği de gözden kaçırılmamalıdır. Kendinden sonraki neslin siyasi mücadelesinin başlangıcı olan Nîmânın şiiri, kısır ve sınırlı bir siyasi anlayıştan kaynaklanmayıp aksine insani romantik bir ruhtan kaynaklanmıştır (Ruzbe 1391: 71).

Nîmâ sembolik bir dil kullandığ1 şiirlerini genellikle öykü-şiir şeklinde yazmıştır (Sâlis 1369: 322). Onun toplumsal içerikli şiirindeki siyasi ve içtimai olayların şiirlerine yansıması doğrudan ve sloganist bir şekilde değil, daima kapalı ve sembolik bir dilledir. Nîmầnın şiirinde girift ve kapalı bir anlam dünyası yansıtması Avrupa edebiyatının etkisi ile şiir estetik anlayışının bir gereği olarak algılanabilir. Nîmânın dilindeki bu müphemlik özellikle top- 
lumsal içerikli şiirlerinde okuyucuya geniş bir yorum yapma firsatı vermektedir. Mesela "Morg-i Âmin” şiirindeki kuş, toplumda beklenilen kurtarıcıyı, şairin veya toplumun bilinçaltını ya da bizzat şairin kendisini temsil ediyor olabilir (Ruzbe 1391: 71- 74).

Serbest şiirleri arasında toplumsal ve siyasi içerikli en belirgin şiirleri 1943'de "Nakus", 1947'de "Padeşah-i Fath", 1949'da "Suy-i Şehr-i Hamuş", 1951'de "Morg-i Âmin” adlı şiirleridir (Pûrnâmdâriyân 1389: 99). Ülkeyi sembolize eden şehirde, halkın gafleti ve şairin umutsuzluğu "Suy-i Şehr-i Hamuş" adlı şiirin dizelerine şöyle yansımıştır:

Şehir, uykuya daldı uzun süredir

(besliyor uykuyu şehir

yenilmiş şehir)

Duyulmuyor işte onun

Nefesinin dahi sesi

Vazgeçtiği ülküsüyle

Benziyor bir ölüye (Yûşîc 1389: 689).

"Morg-i Gam” adlı şiirinde keder, hüzün kuşu çehresinde şairle birlikte kimlik kazanmaktadır. Şairin özgür ruhu ve temiz aşkından kaynaklanan bu hüzün, halkın sıkıntılarına karşı şairde hassasiyet oluşturmuştur. Çaresiz zavallı halkın durumu, istismarcı zalim kimselere karşı duyduğu nefreti içeren siyasi ve toplumsal içerikli şiirlerinde de şair yine söz konusu halka duyduğu aşktan ve mukaddes hüzünden güç almaktadır. Nîmâ’nın şiirlerinde ne zaman bu aşktan söz edilse üzüntü ve acı da birlikte gelmektedir. Herkesin şahsi çıkarını düşündüğü bir toplumda hakkını aramanın bedeli olan bu aşktan kaynaklanan sıkıntı ve üzüntüye tahammül Nîmânın düşüncesinde somutlaşır (Pûrnâmdâriyân 1389: 100):

Bu gam duvarının üzerinde, yükselen duman gibi,

Daima oturmuş bir kuş, yaymış kanatlarını, Öyle ki kederli düşünceler sarmış, salladığı başını (Yûşîc 1389: 331).

Nîmânın şehir ve şehirlilerden nefreti, inzivaya çekilmesi insanlardan bir kaçış olarak değil, riyakârların riyası ile kirlenme, bencil insanların tuzağına düşerek başkalarının hâlini anlamaktan gaflete düşmekten korkması olarak değerlendirilebilir. O inzivaya çekildiği zamanlarda sessiz kalmamıştır. İran1 araştırmacı Muhammet Tâkî Pûrnâmdâriyân, Nîmâ Yûşic'in daima doğruluğa ve dürüstlüğe olan tutkusu ile yaşamda karşılaştı̆̆ acılara tahammül ettiğini, fakat bazen de kendi düşüncelerinde vesveseye kapılarak oyuna eğ- 
lenceye kendini veren şöhret peşinde koşan dertsiz tasasız insanlara katılmak arasında ikilem yaşadığını belirtmiştir. Ona göre şairin "Hane-yi Servilı̂" adlı şiiri onun içindeki bu iki zıt yönün savaşını anlatmaktadır; şiirde taraflardan biri temiz kalpli köylü şairi temsil eden Servilî diğeri ise Şeytan'dır (1389: 103). Şeytan'ın Servilî̀nin evine girme mücadelesi sonunda başarıya ulaşmı̧̧tır. Şeytan, Servilî̀yi ikna edip evine girmiş, onun zihninde şüpheler yaratmıştır. Bu şekilde masumiyetini bir nebze de olsa kaybeden Servilî’nin yaşamı artık eskisi gibi olmayacaktır. Nîmâ bu şiirde Servilî karakteriyle masumiyeti, Şeytan karakteri ile kirlenmişliği sembolize ediyor olabilir.

1924 y1lında “"Mahbes ve "Harken”, 1925 yilında "Hanevade-i Serbaz", 1926 yılında "Şam'-i Karaci” ve “Came-yi Maktul”, 1944 y1lında "Maderi ve Pasari”, 1945 yılında "Naravayi be Rah" ve "Manli”, 1946 y1lında "Kar-i Şebpa”, 1948 yılında "U be Ru'yayeş", 1952 yılında "Dar Nohestin Saat-i Şeb” adlı şiirleri doğrudan ya da dolaylı olarak halkın çektiği sıkıntılar ve dayanılmaz zahmetlerle ilgili yazdığı diğer şiirleridir. Nîmâ Yûşic bazen şiirlerinde sadece olan durumu tasvir ederek bazen de halka öfkelenerek onları yaşadıkları zulme ve içinde bulundukları ortamı değiştirmek için mücadeleye teşvik etmeye çalışıştır (Pûrnâmdâriyân 1389: 109). Söz konusu şiirlerde genellikle olumsuz koşullar içerisindeki kişilerin umudunu diri tutmaya çalışmaları resmedilmiş, varlık ve yokluk içinde yaşayan insanların hayata tutunma maceraları anlatılmıştır. Tabiat unsurlarının kişilerin duygu ve düşüncelerine göre şekil aldığı şiirlerde oluşturulan ortam oldukça canlı ve etkileyicidir.

"Mahbas" toplumu eleştiren bir şiirdir. Şiirin kahramanı Kerem adında bir köylü çocuğudur. Kerem toprak sahibine itaatsizlikten hapse düşmüştür. Bir zindan koğuşunun tasvir edildiği bu şiirde zindanın şairin içinde bulunduğu ortamı ve özgürlük nimetinden yoksun bir memleketi çağrıştırıyor olabilir:

Kafes gibi dar bir koğuşun dibinde, dövdüler çanı tam beş kez Açıldı birden karanlığın kapısı, hapishanenin eski siyah kapısı

Yanan mumun yanında, topladığı dizlerine başını koymuş (Yûşîc 1389: 100).

1926 yılında yayımlanan, kocası savaşa giden bir köylü kadını hikâye eden "Hanevade-yi Serbaz" Nîmâ Yûşic'in en başarılı şiirlerindendir (Âjend 118788). Bu şiirde "Efsane" ve "Ey Şeb" adlı şiirlerdeki bireysel kötümserlik ve karamsarlık biraz hafiflemiş şekliyle varlık bulmaktadır. Rusya'ya savaşa giden bir askeri anlatan şiir, bedbaht ve fakir bir halkın hikâyesidir (Âryenpûr1387: 477). Toplumdaki fakirliği dert edinme Nîmânın şiirinin özünü oluşturmaktadır. Benzer şekilde "Kar-i Şebpa" adlı şiirde gece kendi pirinç tarla- 
sını bekleyen fakir bir köylüyü anlatmaktadır (Âjend 1363: 188). İşçilerin sömürülmesini pirinç tarlasındaki gece bekçisi üzerinden anlattığı bu şiirde gece bütün karanlığıyla bekçinin üzerine çökmüştür. Uzun bitmek bilmeyen gecede bekçinin evde aç, ekmek bekleyen çocukları aklından çıkmamaktadır. Bekçi dişini tırnağına takarak yetiştirdiği pirinç tarlasından elde edeceği gelirin umuduyla sıcak ve nemli geceye tahammül etmektedir. Annesi ölmüş çocuklarını yalnız evde bırakan bekçinin zihni çocukları ve pirinç tarlası arasında gidip gelmektedir. Sonunda evde açlikla mücadele eden çocuklar ölüme yenik düşerler. Nîmầnın bu şiirde olduğu gibi gece içerikli şiirleri son derece karamsar ve kötümserdir. Zira Rıza Han’ın elli yıllık diktatörlüğ̈ karanlık bir gece gibi ülkeyi kuşatmıştır. Rıza Han'dan sonra oğlu da bu istibdat yönetimini sürdürmüştür (Karaguzlu 1386: 228-230). Şiirde gece bekçisinin bitmeyen 1stırabı Rıza Pehlevi’nin bir türlü son bulmayan baskıcı yönetimiyle örtüştürülebilir:

Ne 1stırap dolu ağır bir gece! Evet

Onun söylediği gibi.

Korkunç ve uzun ormanın köşesinde gölge.

Söndü ateş

Çocuklar buz kesmiş bedenleriyle hareketsiz,

Elele tutmuş her ikisi uyumuş

Kendinden geçmiş, ebedi uykuya dalmış (Yûşîc 1389: 616).

1925-1926 yılları arasında yazdığ 1 "Beşaret”, "Az Tarkeş-i Ruzgar”, "Galb-i Gavi”, "Şehid-i Gomnam”, "Serbaz-i Fuladin” adlı şiirleri Nîmâ’nın yaşadığ1 çağda yolunda gitmeyen durumlara muhalefet ettiği siyasi şiirlerindendir. Nîmâ’nın inkılap düşüncesini anlattığ1 şiiri "Padeşah-i Fath"dir. Toplumun sessiz bir güç unsuru olduğunu, halkın üzerindeki baskı ve zulmü alt edeceğine inancın anlatıldığı bir şiirdir (Pûrnâmdâriyân 1389: 110).

Nîmânın toplumsal içerikli şiirlerinden olan "Nakus", şairin her şeyin düzeleceğine olan inancını yansıttığı ümit içerikli şiirlerindendir. Gaflet uykusunda uyuyan halkı uyandıracak olan Nakus (çan sesi) seherin karanlık havasını açacak, soğuk duvarını yıkacaktır. On iki kıtadan oluşan şiir, her kıtasında "ding dang” diyerek çanın sesi ile başlamaktadır. Şiirde baştan beri toplam on iki kez çalan çanın sesi gecenin on iki saat oluşuyla alakalı olmalıdır. Çanın her çalışı geçen saati ifade etmekte, on ikinci çalışı gecenin bitimi anlamına gelmektedir. Şiirde değişim içindeki toplum tasvir edilmektedir. 


\section{Nîmâ Yûşic'in Sembolik Şiirleri}

Klasik Fars şiiri temsil ve sembollü anlatımlarla doludur. Temsil dolaylı ve kinayeli bir anlatıma sahiptir. Temsile konu olan iş, olay ve eşyanın muhtevası ve mesaj1 sembolik bir anlam ifade etmektedir. Şiir ve hikâyede söz konusu görüş düşünce ve ya sonucun ifade edilmesinde kullanılan kelimeler gerçek ve bilinen anlamlarıla kullanılmazlar. Sembolik şiirde ise tam aksine şairin düşünceleri ve şiirin mesajı intikal edilen kelimelerin yardımıyla olur, kelimelerin mefhum ve çağrışımları muhtevanın anlaşılmasını sağlar. Nîmâ Yûşic şairliğinin ilk yıllarında klasik dönem şairlerinin kullandığı şekliyle temsili kullanmış şiirinde tam olarak sembolik bir dil yakalayamamıştır. Toplumsal, ahlaki ve nasihat içerikli şiirlerini eski şairlerin âşıkane ve hamasi şiirlerde kullandığı akşam, sabah, seher ve gül gibi bilindik kavramlarla dile getirmiştir (Hamîdîyân 1383: 120).

Nîmânın 1940’lı yıllarda yazdığı yaklaşık otuz temsili şiiri vardır. Oldukça genç yaşta yazdı̆̆ bu şiirleri eski şairleri taklitten öteye geçememiştir. Bunların yarısından çoğu fabl tarzı şiirlerdir, geri kalanı ise temsili ibretlik kıssalardir. "Engasi”, "Harken”, "Came-i Nov", "Peser”, "Be Ressam Erjengi”, "Hâce Ahmed Hasan Mimendi”, "Abdullah Taher”, "Kanizak”, Keçebi”, “Amu Recab”, “Kabk”, “Ateş-i Cehennem”, "Mirdamad”, “Gonbad”, "Heybere” adlı şiirleri eleştiri ve mizah içerikli temsili kıssalarıdır. Eski şairlerin şiirlerine öykünerek yazılan Nîmâ’nın bu şiirleri onların şiirlerine nispeten daha anlaş1ır ve açıktır (Hamîdîyân 1383: 121). Nîmâ’nın bu tarz yazdığ1 şiirlerden olan "Keçebî” civcivlerini alan kartalı önlemek için köyün köprüsünü yıkan saf köylünün cehaletini şu şekilde dile getirmiştir:

Gördü Keçebî korkusuzca dolaşan kartalı

Götürüyorken tek tek civcivlerini,

Bulmak istedi bir çare

Aldı yanındaki baltayı.

Düştü kartalın peşine

Yıkt1 yol üstündeki köyün köprüsünü.

Bilmedi düşmanın yolunu.

Vurdu baltayı kendi yoluna (Yûşîc 1389: 212). 
“Şem'-i Karaci” ve "Ku” adlı şiirleri Nîmâ’nın sembolik şiire alıştırmaları mahiyetindedirler. Şair bu şiirlerinde temsili şiirlerinde yaptığ 1 gibi belli bir sonuç çıkarmaya çalışmaz ve şiirdeki sembolleri açılamaya ve tefsir etme çabasına girmez. Bu farklılıklar değersiz gibi gözükse de sembolik şiire geçiş evresinde önemli detaylardır. İçerik ve muhteva olarak da bu iki şiir farklı ve yenidir. Dil açısından da Nîmâ Yûşic eski şairlerden uzaklaşarak kendine özgü bir söylem geliştirmeye başlamıştır (Hamîdîyân 1383: 133). Nîmâ özgürlüğe ve daha güzel bir dünyaya aç1lma arzusunu kuğu gibi zarif ve narin bir kuş üzerinden sembolize etmiştir:

Çırparak ayaklarını, belki de Atıyordu yorgunluğunu bedeninden.

Beyaz kanatlarını açarak Vadinin karşısından uçarak.

Uçsun oradan denize kadar

Seher misali geniş bir fezanın aşağısına

Gitsin bizim zalim dünyamızdan Çırpsın karanlığın ortasında, kanat (Yûşîc 1389: 161).

İran edebiyatında toplumsal meselelerde sembolik bir dil kullanılması Nîmâ’nın şiiriyle ortaya çıkmıştır. Tasavvuf edebiyatındaki sembolik dil; âşık, maşuk, mutluluk, hüzün, vuslat, hicran gibi sade başlangıç düzeyi sembollerdir. Bütün tasavvufi kavramların kullanılmasıyla tasavvufi şiirinin kemale ermesi özellikle Nizâmî Gencevî̀nin katkılarıyla aşk şiirlerinde tasavvufi terim, kavram ve sembolleri kullanmasıyla başlamıştır. Tasavvuf şiiri beşinci yüzyılın sonundan sekizinci yüzyılın sonlarına kadar en yaratıcı ve yenilikçi çağını yaşamıştır. Hüseyin bin Mansûr'un halifenin dini çevrelerce tahrik edilmesiyle öldürülmesinden sonra tasavvuf edebiyatında arif meşrepli şairlerin zahir ehline karşı duydukları endişe ile semboller kullanmaya başland1ğ1 düşünülmektedir. Nîmânın şiirinde sembolik bir dil kullanması da Rıza Şah Hükümeti'nin baskıcı ve siyasi ortamın boğuculuğuna yorumlanmıştır. Söz konusu husus şairin sembolik anlatıma yönelmesindeki etkenlerden biri olsa da tek sebep değildir. Bu şekilde bir anlatım tarzının seçilmesi edebi ve sanatsal anlamda kapalı anlatımın kabul görmesi ile alakalıdır. Toplumsal içerikli şiirde sembolik dilin kullanılması Nîmâ Yûşic ile başlamış, Mehdi-i Ehavân-i Sâlis, Ahmed Şâmlû ve diğer takipçilerle farklı şekiller almıştır. Nîmânın sembolik şiire yönelmesinde onun Charles Baudelaire, Arthur Rimbaud, Stephane Mallarme gibi Fransız sembolik şairleriyle tanışmasının etkisi vardır. Fakat daha çok şekil ve sembolik üsluplarından etkilenmiş 
konu, içerik, duygu dünyası ve hayal gücü olarak kendi ülkesinin kültürüne uygun bir bakış açısı geliştirmiştir. Nîmânın şiirinin kendinden sonrakiler tarafindan beğenilmesi ve kabul görmesi de bu durumla ilişkilendirilmiştir (Hamîdîyân 1383: 149).

Nîmânın sembolik şiir yazarken tasavvuf edebiyatında hayvanların diliyle anlatılan hikâyelerden etkilenme olasılı̆̆ı vardır. Birkaç temsili şiiri haricinde o, canlılardan ve onların özelliklerinden daha çok simge yoluyla faydalanmıştır. Nîmânın şekil verdiği sembolik dilde Fars edebiyatındaki hamasi metinlerden etkilenmesi de söz konusu olabilir. Zira onun şiirinde efsanevi bir ruh müşahede edilmektedir. Onun şiirinde sadece canlllar konuşmaz, cansız tabiat unsurları bulut, rüzgâr, 1rmak, dağ ve bitkiler sanki canlı bir dünyada efsanevi bir şekilde insan gibi varlık gösterirler. Aynı şekilde efsanelerdeki gibi dev, peri, ejderhalar, Kaknus ve Simurg gibi efsanevi kuşlar görülmektedir. Nîmầnın şiirinde tabiat olaylarının tasvirinde, özellikle isim belirtilmemiş olsa da, efsanevi varlıklara benzer unsurlar vardır.

1927 yılından itibaren Rıza Şah'ın güçlenmesiyle boğucu ve korkutucu bir ortamın hâkim olması sonucunda temsili hikâyeler siyasi ve toplumsal şiirlerin yerini almaya başlamıştır. 1927 yılından sonra ilk serbest şiir olan "Kaknus" ile temsili hikâyeler dönemi son bulur. 1938 y1lının sonlarından itibaren II. Dünya Savaşı'nın başlaması ve Rıza Han'ın iktidarının tehlikeye düşmesiyle siyasi ve toplumsal şiirler sembolik bir dille tekrar söylenmeye başlamıştır. 1937 yılından sonra Nîmầnın şiirlerine bir belirsizlik yansımaya başlamıştır. Bu belirsizlik zamanla şairin şiirinin asli özelliklerinden biri haline gelmiştir. Yaşanılan siyasi ve toplumsal gerçekler onun şiirinde farklı duygular uyandırmıştır. Nîmầnın ümidin hâkim olduğu şiirleri oldukça azken ümitsizlik ve karamsarlığın hâkim olduğu şiirleri oldukça fazladır (Pûrnâmdâriyân 1389: 120).

Nîmâ Yûşic bir şairin şiir yazarken neden yazdığını ve topluma nasıl bir katkı sağladığını düşünmesi gerektiğini dile getirmiştir (Yûşic 1385: 312). Bu bağlamda kendisi şiirlerinde, sembolik dili toplumun gerçeklerini ifade etmek için kullanmıştır. Düşüncelerinin kalıcı ve etkili olmasını arzu eden Nîmâ, hayatı boyunca yeni bir söylem biçimi ortaya koyma çabası içinde olmuştur (Balc1 2018: 85).

Nîmâ Yûşic 1948 yılında yazdığı karamsar şiirlerin ardından ümit dolu şiirler yazmaya başlamıştır. "Bar Feraz-i Daşt” adlı şiiri de bu tarz şiirlerdendir. Şiirde çölün üzerini her canlıyı nasiplendirecek acayip bir yağmur bulutu kapla- 
mıştır. "Suy-i Şehr-i Hamuş" adlı şiirde de zulüm görmüş uykuya dalmış bir şehir tasvir edilmektedir. Bütün olumsuzluklara rağmen sessiz şehirde diriliş marşı çalmaktadır. Uzak yoldan bir kafile şehre gelerek damarları kurumuş uyuyan şehri uykudan uyandırmaktadır. Bu şiirde bozguncu ve zalimler anlatılmıştır. Şehir halkının onların aldatmacalarından kurtulup doğruyu yanlışı, dostu düşmanı kendisi ayıracak duruma geleceği umut edilmektedir. "Cadde Hamuş ast” adlı şiir de karanlık bir ormanda her yeri sessizlik bürümüştür. Fakat bu karanlık gecenin ardından her an sabah olacakmış gibi bir tasvir söz konusudur. "Bar Feraz-i Dudhayi" adlı şiirde yanan bir geminin üzerinden kalkan dumanlardan sonra gökyüzü yağmuru müjdelemektedir. "Notfeband-i Dovran", "Had" ve "Name be Yak Zendani" adlı şiirlerde ise karanlıkların içinde saklı umudu görmekteyiz (Pûrnâmdâriyân 1389: 146):

Kapatmalarına rağmen

Bütün yolları ve kapıları

Gelecek o, doğru haberiyle.

Yürüyüşü nazlı

O mest sevgiliyle (Yûşî̀ 1389: 161).

Nîmâ Yûşic'in serbest şiirlerinde kuşların ayrı bir yeri vardır. Bu şiirlerde şairin hayata bakış açısını ve değer yargılarından izler bulmak mümkündür. Şiirlerine konu olan Kaknus adlı efsanevi kuş ve Mazenderan şehrinin yerli kuşu Tuka kuşları gibi kuşlar şiirde şairin kendisini ya da kendi gibi olan sanatçıları sembolize ettiği şiirlerdir (Hasanli 1386: 342). Kuşlar onun ruhi ve hissi boyutunu, şahsiyetinde gizli kalmış iç dünyasını yansıtmaktadırlar. İranlı araştırmacı ve yazar Takî Pûrnâmdâriyan, Nîmâ'nın "Gorab” adlı şiirde yalnızlığın ve muhaliflerinin gözünde uğursuz oluşunu, "Morg-i Mocesseme"de kendisinin inzivaya çekilmekle birlikte etrafinda yaşananlardan gafil olmadığını ve hayata karşı duyduğu endişeyi, "Morg-i Gam”da duçar olduğu şiddetli gam ve kederini anlattığını ifade etmiştir. Benzer şekilde "Agatuka" adlı şiirde sürekli okuyup yazmasına rağmen şairin kıymetinin bilinmezliğini, önemsenmemezliğini ve içine düştüğü ümitsizliği, "Morg-i Âmin”de şairin halka karşı sorumluluk bilincini ifade ettiğine değinmiştir (1389: 140). Nîmâ’nın şiirinde kullandığ rin yaratıcılığı sayesinde anlaşılır bir tarafı olan sembolik şiirleri yine de farklı yorumlanma özelliğine sahiplerdir (Hasanli 1386: 342). 


\section{SONUÇ}

Nîmâ Yûşic İran toplumunda zuhur eden siyasi olayların ve hükümetlerin uygulamalarının halk üzerindeki yansımalarını şiirlerinde yansıtmaya çalışmıştır. Yanlış siyasetin halkın üzerinde doğurduğu olumsuz etkileri dikkatlice gözlemlemiş, halkın verdiği tepkileri anlamlandırmaya gayret etmiştir. Egemen kesimin toplum üzerindeki baskısının arttığı dönemlerde şair ve yazarların kendi kimliklerinden verdiği tavizleri eleştirmiştir. Onlar gibi olmamak için kendini toplumdan soyutlamış, bu tarz durumlarda toplumun dışında kalmayı yeğlemiştir.

Fantastik, hayal ürünü şiirlerden ziyade bizzat tanık olduğu olayları, hissettikleri şiirlerine yansıtan Nimẩnın şiiri, kendisi ile iç içedir. Şair, kâh içinde yaşadığı toplumun sorunlarından şiirine sığınmış, kâh gelecek güzel günlerin beklentisiyle ümit dolu şiirler yazmıştır. Bazen romantik duygularının etkisinde kalarak sadece bireysel duygularını ifade etmiş bazen de hissettiği ve gördüğü olayları dile getirmesi gerektiğine inanarak kalemine sarılmıştır.

Nîmâ Yûşic, Fransız şiirinin etkisiyle şekil verdiği sembolik şiirini kendi toplumunun anlayışıyla yoğurmuştur. Nîmầnın sembolik bir şiir dil oluşturmasında siyasi olayların tesiri olduğu gibi şairin eğilimleri de etkilidir. Hikâye tarzında yazdığı şiirlerinde diyaloglara yer veren şair, yaşadığı çağın sorunları$\mathrm{n} ı$ bu şekilde daha iyi dile getirdiğine inanmıştır. Dolaylı yollardan değindiği sorunları, duygu ve düşüncelerini farklı karakterler üzerinden dile getirmiştir.

Nîmâ Yûşic ortaya koyduğu yeni şiirini klasik şiirin özelliklerini modernize ederek çağa uygun, yaşadığı zamanın ihtiyaçlarına cevap verebilecek bir hale getirmeye gayret etmiştir. Nîmânın bilinçli olarak yapılandırdığı yeni şiiri, dereceli olarak şekil almıştır. Modern çağın gereklerini beyan edebileceği ve aynı zamanda ülkesinin kültürüne uygun olarak şekillendirdiği şiir anlayışı kendinden sonraki şairler için örnek teşkil etmiştir. 


\section{KAYNAKLAR}

Abbâs Âbâd, Yusuf Ali (hş. 1390) Caryanşinasi-i Şirr-i Mu'asır, Tahran: İntişarat-1 Hermes.

Âjend, Yakub (hş. 1363), Edebiyat-i Novin-i İran, Tahran: İntişarat-1 Emir Kebir.

Âryenpûr, Yahya (hş. 1387).Ez Sabâ ta Nîmâ, C.2, Tahran: İntişarat-1 Zevvar.

Balc1, Musa (2018). Filoloji Alanında Yeni Yaklaşımlar, (Şiir Ve Mitoloji Bağlamında Feridüddîn-i Attâr Ve Nîmâ Yûşı̂̀c’in "Kaknus" Şiirlerini Birlikte Okumak), Ankara: Gece Akademi.

Caferî, Mesud (hş. 1386). Seyr-i Romantism dar İran, Tahran: Neşr-i Markaz. Hamîdîyân, Sa'ed (hş. 1383). Destan-i Degerdisi. Tahran: İntişarat-i Nilufer

Hukûkî, Muhammed (hş. 1389). Şirr-i Zeman 5: Nîmâ Yûşic, Tahran: İntişarat-1 Negah.

Hasanli, Kâvûs (1386). Guneha-yi Novaveri der Şirr-i Mu'asır-ı İran, Tahran: İntişarat-1 Salis.

Huseynî, Rıza Seyyid ( hş.1387). Mektepha-yi Edebî, C.1, Tahran: intişarat-1 Negah.

Karaguzlu, Muhammed (hş. 1386) Hamsayegan-ı Dard, Tahran: İntişarat-1 Negah.

Kurlangıç, Hicabi (2010). İran Şiirinde Bir Yenilikçi: Nîmâ Yuşic, Nüsha, 30, s. 99-122.

Lengrûdî, Şems (1387). Tarih-i Tahlil-i Şirr-i Nor, cilt 1, Tahran: Neşr-i Merkez.

Pûrnâmdâriyân, Takî (hş. 1389). Haneam Abri Ast, Tahran: Enteşarat-1 Morvarid.

Ruzbe, Muhammed Rıza (hş. 1391). Edebiyat-i Muaser-i İran, Tahran: Neşr-i Zemestan.

Sâlis, Mehdi-i Ehavân (hş. 1369). Bedayi' ve Bid'atha ve Ata ve Lika-yi Nîmâ Yûşic, Tahran: İntişarat-1 Bozorgmehr.

Şâfê̂, Husrev (1380). Zendegi ve Şi ir-i Sed Şa irr, ez Rudeki ta Imruz, Tahran: Ketab-1 Hurşid. 
Şefî Kedkenî, Muhammed Rıza (hş. 1380). Edvar-i Şi'r-i Farsi, Tahran: Neşr-i Sohen.

Şefî Kedkenî, Muhammed Rıza (hş. 1390). Ba Çerağ u Ayine, Tahran: Neşr-i Sohen.

Yıldırım, Nimet (2011). “Fars Şiirinde Nimâ Çağının Devreleri”, İ.Ü. Şarkiyat Mecmuası, 19, s. 143-169.

Yûşic, Nîmâ (1385). Derbare-i Honer ve Şir ve Şa iriri. (haz: Sirûs Tahbâz). Tahran: İntişarat-i Nigah.

Yûşic, Nîmâ (1389). Mecmua-i Kamil Eş'ar. (haz: Sirûs Tahbâz). Tahran: İntişarat-i Nigah. 